$4 \quad{ }^{1}$ Energy Technologies Area, Lawrence Berkeley National Laboratory, Berkeley, CA, 94720, USA

$5 \quad{ }^{2}$ Goldman School of Public Policy, University of California, Berkeley, CA, 94720, USA

$6{ }^{3}$ Civil and Environmental Engineering, University of California, Berkeley, CA, 94720, USA

$7 \quad{ }^{4}$ Joint BioEnergy Institute, Emeryville, CA, 94608, USA

$8 \quad{ }^{5}$ Energy \& Biosciences Institute, University of California, Berkeley, CA, 94720, USA

9

10

$11{ }^{*}$ Corresponding Author

12 Address: Lawrence Berkeley National Laboratory, 1 Cyclotron Road, Berkeley, CA, 94720, USA; MS:

$1390 \mathrm{R} 2004$

14 Phone: (510) 486-4046

15 E-mail: hannabreunig@lbl.gov

16

17

18 Number of Pages: 22

19 Number of Figures: 8

20 Number of Tables: 7 


\section{California Context}

California's climate change policies set ambitious targets for the way in which many sectors conduct business. These include the diversion of $75 \%$ of organic residues from landfills which is estimated to save $4 \mathrm{MMTCO}_{2} \mathrm{eq} / \mathrm{yr}$ (SB 1383), the reduction of GHG emissions from manure management, currently estimated at 11.5 $\mathrm{MMTCO}_{2} \mathrm{eq} / \mathrm{yr}$ (AB 32; SB 1383), the control of agriculture and forestry residue burning which contributes to poor air quality as well as $0.1 \mathrm{MMTCO}_{2} \mathrm{eq} / \mathrm{yr}$ in GHG emissions (Title 17; SB 1260), and 50\% renewable electricity by 2030 (SB 350). ${ }^{1}$ These policy drivers are likely to foster significant growth in California's bioenergy and compost industries, which in turn raises the question as to whether there may be adequate markets for bioenergy byproducts and compost. At the same time, improved management of the state's rangelands (e.g. annual grasslands, oak woodlands, and shrublands $\sim 15$ million hectares $)^{2}$ and croplands $(\sim 3.3$ million hectares $),{ }^{3}$ together referred to as working lands, has come under attention as a viable climate mitigation strategy. ${ }^{4}$ For example, improved management of natural and working lands, including forests and wetlands was estimated to contribute $15-20 \mathrm{MMTCO}_{2} \mathrm{eq}$ savings towards the state's 2030 GHG target of 40\% below 1990 levels under SB 32 .

California has $\sim 3.3$ Mha of cropland and $\sim 15$ Mha of rangeland, some of which was classified as critical (2.6 million ha) or important (1.3 million ha) for conservation by the California Rangeland Conservation Coalition. These classifications were assigned to land parcels using expert opinion on biological value and the output of a Marxan site-selection algorithm to classify land (Figure 4). ${ }^{5}$ We use the resulting shapefile in this analysis to approximate transportation distances. We use county centroids and dairy farms to represent biochar or digestate origin for the Gross and Technical scenarios, and use hypothetical gasification and AD facilities sited by the LBNL ORFI model to represent byproduct origin in the Market scenario. Finally, we use wastewater treatment facilities and hypothetical gasification facilities to represent digestate and biochar origin in the WWT scenario.

\section{Biochar and digestate yields:}

Biochar yields are a function of the processing conditions (e.g. temperature), technology (e.g. slow or fast pyrolysis or gasification), and feedstock (e.g. lignin content, ash content). We use temperature as the primary determinant of biochar yield, pulling values from experiments which characterize biochar yields at temperatures between $300-1100{ }^{\circ} \mathrm{C}$. As the temperature intervals and frequency of biochar sampling vary between literature, we fit exponential, polynomial, logarithmic, power equations to predict yields for three selected temperatures for modeling each biomass feedstock (Table S1). Biochar, bio-oil, and syngas optimizing scenarios use a temperature of $447^{\circ} \mathrm{C}, 778^{\circ} \mathrm{C}$ and $1025^{\circ} \mathrm{C}$, respectively. We first prioritize equations which produce non-negative values for the given temperature range, then those which capture the most variance.

For forestry, green, cardboard, lumber, and paper wastes from the forest and municipal solid waste streams we apply yields from Ronsse and colleagues' fixed-bed slow pyrolysis of pine wood. $\frac{1}{}$ We use Naeem and colleagues' pyrolysis of wheat straw and rice for poaceae species resulting from field and processing industry waste streams. ${ }^{6}$ For fruit species derived from orchard and vineyard residues, we fit yields from Claoston and colleagues' slow pyrolysis of palm oil empty fruit bunch. ${ }^{7}$ We match results for citrus species from the same sector using Lam and colleagues' experiment. ${ }^{8}$ We apply yields from Angin's pyrolysis of safflower seed cake and Demirbas and colleagues' slow pyrolysis of nut and legume 
63

64

65

66

67

residues for those nut, seed, and legume residues found in orchard, vineyard, processing industry and field waste streams. ${ }^{9-11}$ Specifically for cotton and cotton gin trash found in field and processing industry waste we use pyrolysis yields from Zabaniotou and colleagues. ${ }^{12}$ Overall yields range from $16 \%$ to $31 \%$ of this original disposed biomass. Fixed carbon content is presented in Table S2.

Table S1. Assumptions regarding biochar yield.

\begin{tabular}{|c|c|c|c|c|c|c|}
\hline Biomass Residue & Proxy & Reference & Fitting equation & $\begin{array}{l}\text { Biochar Yield @ } \\
1025\end{array}$ & $\begin{array}{l}\text { Biochar Yield @ } \\
778\end{array}$ & $\begin{array}{l}\text { Biochar Yield @ } \\
477\end{array}$ \\
\hline almond & safflower seed cake & Angin 2013 & $y=37.465 e-7 E-04 x$ & $18 \%$ & $22 \%$ & $27 \%$ \\
\hline almond hulls & rice husk & Claoston et al 2014 & $y=10296 x-0.91$ & $19 \%$ & $24 \%$ & $38 \%$ \\
\hline almond shells & almond shell & Demirbas 2006 & $y=-1 E-05 x 2-0.0228 x+42.041$ & $8 \%$ & $18 \%$ & $29 \%$ \\
\hline apple & palm oil empty fruit bunch & Claoston et al 2014 & $y=10250 x-0.964$ & $13 \%$ & $17 \%$ & $27 \%$ \\
\hline apricot & palm oil empty fruit bunch & Claoston et al 2014 & $\mathrm{y}=10250 \mathrm{x}-0.965$ & $13 \%$ & $17 \%$ & $27 \%$ \\
\hline avocado & palm oil empty fruit bunch & Claoston et al 2014 & $y=10250 x-0.966$ & $13 \%$ & $17 \%$ & $27 \%$ \\
\hline barley & wheat straw & Naeem et al 2014 & $y=3195.7 x-0.737$ & $19 \%$ & $24 \%$ & $34 \%$ \\
\hline beans \& peas dry & corncob & Demirbas 2004 & $y=3 E-08 \times 3-7 E-05 x 2+0.0155 x+29.523$ & $4 \%$ & $13 \%$ & $24 \%$ \\
\hline cannery & tomato green waste & Smider 2014 & $y=41.62 e-4 E-04 x$ & $28 \%$ & $30 \%$ & $34 \%$ \\
\hline cardboard & wood & Ronsse et al 2013 & $y=2587.3 x-0.729$ & $17 \%$ & $20 \%$ & $29 \%$ \\
\hline cherry & palm oil empty fruit bunch & Claoston et al 2014 & $y=10250 x-0.968$ & $13 \%$ & $17 \%$ & $27 \%$ \\
\hline citrus other & orange peel & Shiung et al 2019 & $y=45745 x-1.184$ & $13 \%$ & $17 \%$ & $31 \%$ \\
\hline corn & corncob & Demirbas 2004 & $y=3 E-08 \times 3-7 E-05 x 2+0.0155 x+29.523$ & $4 \%$ & $13 \%$ & $24 \%$ \\
\hline cotton & cotton gin trash & Zabaniotou et al. 2000 & $y=-42.93 \ln (x)+319.36$ & $22 \%$ & $34 \%$ & $55 \%$ \\
\hline cotton gin trash & cotton gin trash & Zabaniotou et al. 2000 & $y=-42.93 \ln (x)+319.36$ & $22 \%$ & $34 \%$ & $55 \%$ \\
\hline date \& fig & palm oil empty fruit bunch & Claoston et al 2014 & $y=10250 x-0.963$ & $13 \%$ & $17 \%$ & $27 \%$ \\
\hline dehyd. & tomato green waste & Smider 2014 & $y=41.62 e-4 E-04 x$ & $28 \%$ & $30 \%$ & $34 \%$ \\
\hline exotic & palm oil empty fruit bunch & Claoston et al 2014 & $y=10250 x-0.967$ & $13 \%$ & $17 \%$ & $27 \%$ \\
\hline field crops unsp. & corncob & Demirbas 2004 & $y=3 E-08 \times 3-7 E-05 x 2+0.0155 x+29.523$ & $4 \%$ & $13 \%$ & $24 \%$ \\
\hline field other & corncob & Demirbas 2004 & $y=3 E-08 \times 3-7 E-05 x 2+0.0155 x+29.523$ & $4 \%$ & $13 \%$ & $24 \%$ \\
\hline forest slash & wood & Ronsse et al 2013 & $y=2587.3 x-0.729$ & $17 \%$ & $20 \%$ & $29 \%$ \\
\hline forest thinning & wood & Ronsse et al 2013 & $y=2587.3 x-0.729$ & $17 \%$ & $20 \%$ & $29 \%$ \\
\hline fruits \& nuts unsp. & palm oil empty fruit bunch & Claoston et al 2014 & $y=10250 x-0.964$ & $13 \%$ & $17 \%$ & $27 \%$ \\
\hline grain chaff & wheat straw & Naeem et al 2014 & $y=3195.7 x-0.737$ & $19 \%$ & $24 \%$ & $34 \%$ \\
\hline grape & palm oil empty fruit bunch & Claoston et al 2014 & $y=10250 x-0.963$ & $13 \%$ & $17 \%$ & $27 \%$ \\
\hline green & wood & Ronsse et al 2013 & $y=2587.3 x-0.729$ & $17 \%$ & $20 \%$ & $29 \%$ \\
\hline kiwifruit & palm oil empty fruit bunch & Claoston et al 2014 & $\mathrm{y}=10250 \mathrm{x}-0.965$ & $13 \%$ & $17 \%$ & $27 \%$ \\
\hline lemon & orange peel & Shiung et al 2018 & $y=45745 x-1.183$ & $13 \%$ & $17 \%$ & $31 \%$ \\
\hline lumber & wood & Ronsse et al 2013 & $y=2587.3 x-0.729$ & $17 \%$ & $20 \%$ & $29 \%$ \\
\hline mill residue & wood & Ronsse et al 2013 & $y=2587.3 x-0.729$ & $17 \%$ & $20 \%$ & $29 \%$ \\
\hline nectarine & palm oil empty fruit bunch & Claoston et al 2014 & $y=10250 x-0.966$ & $13 \%$ & $17 \%$ & $27 \%$ \\
\hline nuts other & safflower seed cake & Angin 2013 & $y=37.465 e-7 E-04 x$ & $18 \%$ & $22 \%$ & $27 \%$ \\
\hline oats & wheat straw & Naeem et al 2014 & $y=3195.7 x-0.740$ & $19 \%$ & $24 \%$ & $34 \%$ \\
\hline olive & olive husk & Demirbas 2004 & $y=-2 E-08 \times 3-2 E-05 \times 2+0.0059 x+43.149$ & $7 \%$ & $26 \%$ & $39 \%$ \\
\hline orange & orange peel & Shiung et al 2018 & $\mathrm{y}=45745 \mathrm{x}-1.183$ & $13 \%$ & $17 \%$ & $31 \%$ \\
\hline other nut shells & walnut shell & Demirbas 2006 & $y=-3 E-05 x 2+0.0102 x+43.64$ & $23 \%$ & $33 \%$ & $42 \%$ \\
\hline paper & wood & Ronsse et al 2013 & $y=2587.3 x-0.729$ & $17 \%$ & $20 \%$ & $29 \%$ \\
\hline peach & palm oil empty fruit bunch & Claoston et al 2014 & $y=10250 x-0.963$ & $13 \%$ & $17 \%$ & $27 \%$ \\
\hline pear & palm oil empty fruit bunch & Claoston et al 2014 & $y=10250 x-0.964$ & $13 \%$ & $17 \%$ & $27 \%$ \\
\hline pistachio & safflower seed cake & Angin 2013 & $y=37.465 e-7 E-04 x$ & $18 \%$ & $22 \%$ & $27 \%$ \\
\hline plum & palm oil empty fruit bunch & Claoston et al 2014 & $\mathrm{y}=10250 \mathrm{x}-0.963$ & $13 \%$ & $17 \%$ & $27 \%$ \\
\hline rice & rice husk & Claoston et al 2014 & $y=10296 x-0.91$ & $19 \%$ & $24 \%$ & $38 \%$ \\
\hline rice hulls & rice husk & Claoston et al 2014 & $y=10296 x-0.91$ & $19 \%$ & $24 \%$ & $38 \%$ \\
\hline rye & wheat straw & Naeem et al 2014 & $y=3195.7 x-0.739$ & $19 \%$ & $24 \%$ & $34 \%$ \\
\hline safflower & safflower seed cake & Angin 2013 & $y=37.465 e-7 E-04 x$ & $18 \%$ & $22 \%$ & $27 \%$ \\
\hline seed other & safflower seed cake & Angin 2013 & $y=37.465 e-7 E-04 x$ & $18 \%$ & $22 \%$ & $27 \%$ \\
\hline shrub & wood & Ronsse et al 2013 & $y=2587.3 x-0.729$ & $17 \%$ & $20 \%$ & $29 \%$ \\
\hline sorghum & wheat straw & Naeem et al 2014 & $y=3195.7 x-0.737$ & $19 \%$ & $24 \%$ & $34 \%$ \\
\hline sunflower & cotton gin trash & Zabaniotou et al. 2000 & $y=-42.93 \ln (x)+319.36$ & $22 \%$ & $34 \%$ & $55 \%$ \\
\hline triticale & wheat straw & Naeem et al 2014 & $y=3195.7 x-0.737$ & $19 \%$ & $24 \%$ & $34 \%$ \\
\hline walnut & safflower seed cake & Angin 2013 & $y=37.465 e-7 E-04 x$ & $18 \%$ & $22 \%$ & $27 \%$ \\
\hline walnut shells & walnut shell & Demirbas 2006 & $y=-3 E-05 x 2+0.0102 x+43.64$ & $23 \%$ & $33 \%$ & $42 \%$ \\
\hline wheat & wheat straw & Naeem et al 2014 & $y=3195.7 x-0.738$ & $19 \%$ & $24 \%$ & $34 \%$ \\
\hline
\end{tabular}


Table S2. Assumptions regarding biochar fixed carbon content.

\begin{tabular}{|c|c|c|c|c|c|c|c|}
\hline Biomass Residue & Fixed Carbon [\% dry-wt] & Proxy & Reference & Biomass Residue & Fixed Carbon [\% dry-wt] & Proxy & Reference \\
\hline almond & 0.776 & sunflower seed hull & Antal et al 2000 & lumber & 0.75 & oak wood & Antal et al 2000 \\
\hline almond hulls & 0.776 & sunflower seed hull & Antal et al 2000 & mill residue & 0.75 & oak wood & Antal et al 2000 \\
\hline almond shells & 0.779 & almond shell & Antal et al 2000 & nectarine & 0.555 & banana peel & Lam et al 2019 \\
\hline apple & 0.555 & banana peel & Lam et al 2019 & nuts other & 0.776 & sunflower seed hull & Antal et al 2000 \\
\hline apricot & 0.555 & 5 banana peel & Lam et al 2019 & oats & 0.623 & oat hull & Antal et al 2000 \\
\hline avocado & 0.555 & banana peel & Lam et al 2019 & olive & 0.668 & corn cob & Antal et al 2000 \\
\hline barley & 0.623 & oat hull & Antal et al 2000 & orange & 0.559 & orange peel & Lam et al 2018 \\
\hline beans \& peas dry & 0.668 & corn cob & Antal et al 2000 & other nut shells & 0.638 & walnut shell & Antal et al 2000 \\
\hline cannery & 0.492 & garlic waste & Antal et al 2000 & paper & 0.75 & oak wood & Antal et al 2000 \\
\hline cardboard & 0.75 & oak wood & Antal et al 2000 & peach & 0.555 & banana peel & Lam et al 2019 \\
\hline cherry & 0.555 & banana peel & Lam et al 2019 & pear & 0.555 & banana peel & Lam et al 2019 \\
\hline citrus other & 0.559 & orange peel & Lam et al 2018 & pistachio & 0.776 & sunflower seed hull & Antal et al 2000 \\
\hline corn & 0.668 & corn cob & Antal et al 2000 & plum & 0.555 & banana peel & Lam et al 2019 \\
\hline cotton & 0.668 & corn cob & Antal et al 2000 & rice & 0.472 & rice hull & Antal et al 2000 \\
\hline cotton gin trash & 0.668 & corn cob & Antal et al 2000 & rice hulls & 0.472 & rice hull & Antal et al 2000 \\
\hline date \& fig & 0.555 & banana peel & Lam et al 2019 & rye & 0.623 & oat hull & Antal et al 2000 \\
\hline dehyd. & 0.492 & garlic waste & Antal et al 2000 & $\mathrm{~s}$ forest slash & 0.75 & oak wood & Antal et al 2000 \\
\hline exotic & 0.555 & banana peel & Lam et al 2019 & safflower & 0.776 & sunflower seed hull & Antal et al 2000 \\
\hline field crops unsp. & 0.668 & corn cob & Antal et al 2000 & seed other & 0.776 & sunflower seed hull & Antal et al 2000 \\
\hline field other & 0.668 & corn cob & Antal et al 2000 & shrub & 0.75 & oak wood & Antal et al 2000 \\
\hline forest thinning & 0.75 & 5 oak wood & Antal et al 2000 & sorghum & 0.623 & oat hull & Antal et al 2000 \\
\hline fruits \& nuts unsp. & 0.555 & banana peel & Lam et al 2019 & sunflower & 0.776 & sunflower seed hull & Antal et al 2000 \\
\hline grain chaff & 0.623 & oat hull & Antal et al 2000 & triticale & 0.623 & oat hull & Antal et al 2000 \\
\hline grape & 0.555 & banana peel & Lam et al 2019 & walnut & 0.776 & sunflower seed hull & Antal et al 2000 \\
\hline green & 0.75 & 5 oak wood & Antal et al 2000 & walnut shells & 0.638 & walnut shell & Antal et al 2000 \\
\hline kiwifruit & 0.555 & 5 banana peel & Lam et al 2019 & wheat & 0.623 & oat hull & Antal et al 2000 \\
\hline lemon & 0.559 & orange peel & Lam et al 2018 & & & & \\
\hline
\end{tabular}

71 Similar to biochar, digestate yields from anaerobic digestion (AD) are a function of residence time,

72 temperature (mesophilic versus thermophilic), technology (e.g. batch versus continuous), and feedstock

73 (e.g. solids content). To calculate yields we assume a low, medium, and high yield of $60 \%, 70 \%$ and $80 \%$

74 based on findings from five experiments: Astals and colleagues digestion of pig manure, Pognani,

75 Tambone and colleagues' digestion of the organic fraction of municipal solid waste, Moset, Gomez and

76 colleagues' digestion of cattle manure. ${ }^{13-16}$ Although we identified potentially lower digestate yields, we

77 assume a short mean cell residence time during AD coinciding with the assumed digestate yield range.

$78 \quad$ Biomass Conversion Scenarios:

79 Table S3. Scenario parameter variations for byproduct production, composition, transportation, and soil 80 response.

\begin{tabular}{lrrr}
\hline Variable modified & Moderate & Optimistic & Conservative \\
\hline Distance & base & 0.5 & $2 \mathrm{x}$ \\
Application rate [BDT/ha] & 4 & 50 & 2 \\
NPP change from digestate [Mt-C/ha] & 2.1 & 4.7 & 0 \\
Duration of NPP change from digestate [yr] & 3 & 20 & 1 \\
Duration of $\mathrm{N}_{2} \mathrm{O}$ flux change from biochar [yr] & 50 & 100 & 1 \\
\hline
\end{tabular}


Recent biomass residue resource inventories published at the county level for 2014, 2020, and 2050 are coupled with byproduct yield estimates to predict annual production in our Gross scenario. For the Tech scenario, we assume: (1) $50 \%$ of forestry, and $70 \%$ of municipal woody materials and dry agricultural residues are available for bioenergy; ${ }^{17}$ (2) only manure from the 200 largest dairy farms (size based on dairy cow head count estimates) are used for bioenergy by 2050, matching current estimates for investment in dairy digester projects; (3) $10 \%$ of row crop residues or culled agricultural produce is costeffective to collect for bioenergy production; ${ }^{18}$ (4) low moisture food processing residues suitable for animal feed, such as almond hulls, are not available for bioenergy; ${ }^{18}(5)$ only $70 \%$ of nut shells, rice hulls, and pits are available; ${ }^{17-18}$ and (6) only the fraction of wet municipal and food processing residues that can be diverted to existing $\mathrm{AD}$ infrastructure within the same county of origin are converted to digestate (Table S4 for fractions). ${ }^{18-19}$

Data on excess existing AD infrastructure are modeled using data from Breunig and colleagues and assuming the additional flow rate of organic slurry can be increased to up to $2 \%$ of the wastewater of influent flow rate. ${ }^{18}$ High-moisture municipal solid waste and food processing residues are converted to loading rates assuming pre-processing generates a slurry with $8 \%$ total solids. The fraction of highmoisture municipal solid waste and food processing residues that can be diverted to existing wastewater treatment capacity in-county are presented in Table S4.

For our Market and WWT Policy scenarios, we use the LBNL conversion facility cost model (CFCM), developed and written in Python by the authors, to predict the economically-driven scale-up of costeffective gasification, stand-alone $\mathrm{AD}$, and co-digestion at wastewater treatment (WWT) facilities at a moderate electricity price point. ${ }^{20}$ Facilities are sited and sized based on the availability, distribution, and value of biomass residues, and constructed if the facility is considered sufficiently profitable given modeled capital and operational costs and revenues. In the CFCM model, the cost of wet AD is much cheaper by 2050 than present day values, but not as cheap as co-digestion at WWT facilities. The model predicts excess capacity at 50 WWT facilities gets used in our E Mod WWT scenario, compared to our E Mod AD scenario where 16 stand-alone wet AD facilities are constructed (Figure S1). The WWT are used at much higher annual-profit-to-investment ratios $(\max >0.5$, vs stand-alone $\mathrm{AD}$ 's $<0.2)$, but the few wet AD facilities that are built take in substantially more waste than the WWT facilities. The model sets a limit of 400,000 tonnes per year (tpy) as a facility capacity, and 11 of the 16 are sized at this limit (Figure S2). In contrast, 42 of the 50 WWT facilities co-digesting take in less than 100k tpy, and 28 are predicted to accept less than 30k tpy. Since gasification is not expected to compete for the same types of biomass residues as wet-AD at stand-alone or WWT facilities, the production of biochar is the same in both scenarios. Feedstocks sent to facilities are presented in Table S5.

While it is impossible to accurately predict the changes and effects of markets, policies, and other driving factors on biomass residue production out to 2050, it is useful to explore production scenarios and consider what byproduct management plans offer positive outcomes for a range of future conditions. To our knowledge, no other publication has modeled bioenergy byproduct utilization for soil $\mathrm{C}$ sequestration at the scale of state bioenergy generation scenarios. While previous assessments have reviewed what is known about the effects of biochar and compost amendments on soil properties and climate change, little attention has so far been paid to digestate, composted digestate, or the possible blending of biochar with digestate or compost. Current approaches for estimating potential $\mathrm{CO}_{2}$ sequestration and $\mathrm{GHG}$ emissions 
123 from bioenergy provide little clarity on the framework applied or on whether regional constraints are

124 considered. $^{21}$

125 Table S4. Fractions of high-moisture municipal solid waste and food processing residues that can diverted 126 to existing anaerobic digestion infrastructure within the same county of origin.

\begin{tabular}{|c|c|c|c|}
\hline County & & County & \\
\hline Alameda & $100 \%$ & Orange & $100 \%$ \\
\hline Alpine & $75 \%$ & Placer & $100 \%$ \\
\hline Amador & $79 \%$ & Plumas & $79 \%$ \\
\hline Butte & $90 \%$ & Riverside & $100 \%$ \\
\hline Calaveras & $79 \%$ & Sacramento & $100 \%$ \\
\hline Colusa & $77 \%$ & San Benito & $79 \%$ \\
\hline Contra Costa & $100 \%$ & San Bernardino & $100 \%$ \\
\hline Del Norte & $75 \%$ & San Diego & $100 \%$ \\
\hline El Dorado & $100 \%$ & San Francisco & $100 \%$ \\
\hline Fresno & $100 \%$ & San Joaquin & $100 \%$ \\
\hline Glenn & $81 \%$ & San Luis Obispo & $98 \%$ \\
\hline Humboldt & $100 \%$ & San Mateo & $100 \%$ \\
\hline Imperial & $88 \%$ & Santa Barbara & $100 \%$ \\
\hline Inyo & $75 \%$ & Santa Clara & $100 \%$ \\
\hline Kern & $100 \%$ & Santa Cruz & $100 \%$ \\
\hline Kings & $93 \%$ & Shasta & $100 \%$ \\
\hline Lake & $79 \%$ & Sierra & $75 \%$ \\
\hline Lassen & $75 \%$ & Siskiyou & $80 \%$ \\
\hline Los Angeles & $100 \%$ & Solano & $100 \%$ \\
\hline Madera & $100 \%$ & Sonoma & $94 \%$ \\
\hline Marin & $100 \%$ & Stanislaus & $100 \%$ \\
\hline Mariposa & $100 \%$ & Sutter & $100 \%$ \\
\hline Mendocino & $88 \%$ & Tehama & $100 \%$ \\
\hline Merced & $96 \%$ & Trinity & $76 \%$ \\
\hline Modoc & $75 \%$ & Tulare & $100 \%$ \\
\hline Mono & $81 \%$ & Tuolumne & $98 \%$ \\
\hline Monterey & $100 \%$ & Ventura & $100 \%$ \\
\hline Napa & $89 \%$ & Yolo & $100 \%$ \\
\hline Nevada & $100 \%$ & Yuba & $87 \%$ \\
\hline
\end{tabular}




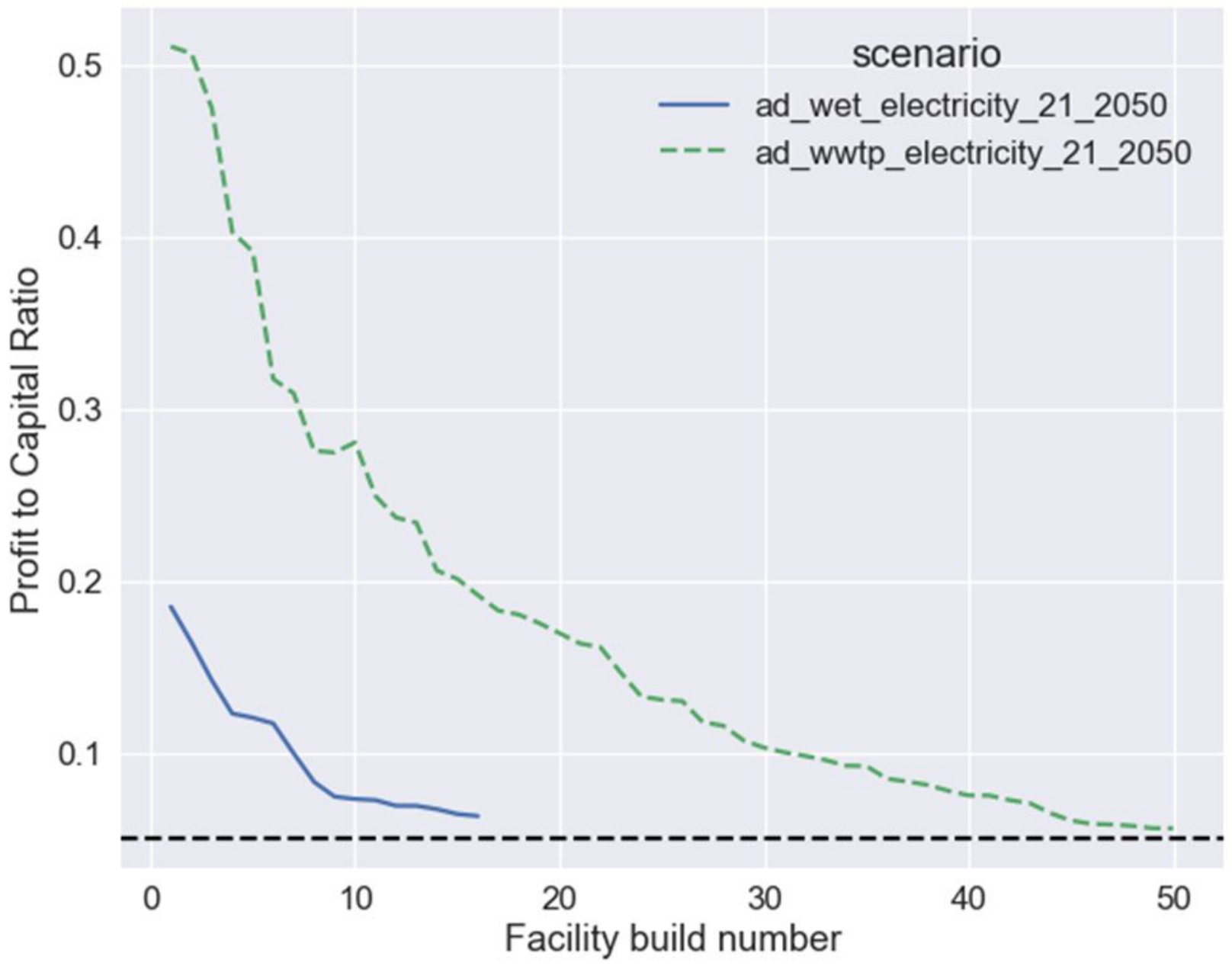

129 Figure S1. Graph showing AD and WWT facilities are built out from greatest-to-least profit/capital ratio. 130 The "build number" is the assigned ID number, and indicates the order in which facilities are built in the 131 LNBL CFCM model. A minimum ratio of 0.05 is set in the model (dashed black line). 


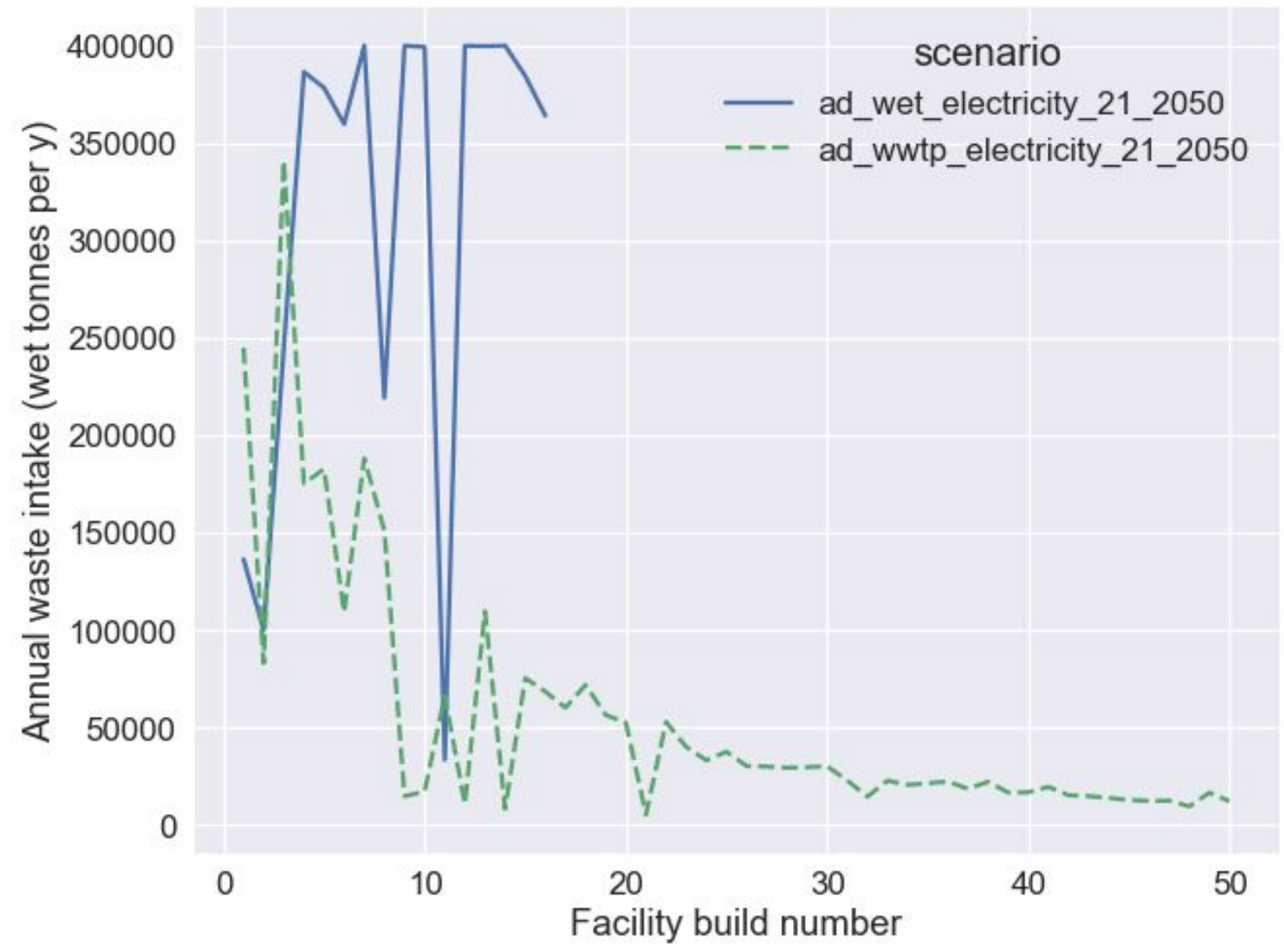

Figure S2. Graph showing the amount of biomass resources converted annually at the AD and WWT 135 facilities predicted based on the 2050 technical biomass resource inventory. Sites are sorted by the "build 136 number", which is the ID number assigned by the model indicating the order in which facilities are built 137 in the LNBL CFCM model. 
Table S5. Biomass residue types converted to bioenergy and byproducts in the LBNL CFCM model, by facility type. All three facilities types are run separately without competition.

\begin{tabular}{|c|c|c|c|}
\hline Biomass residue type & Wet stand-alone AD & WWT AD & Gasification \\
\hline MSW food waste & 3187207 & 1527417 & 0 \\
\hline Brewery wet & 1202265 & 834711 & 0 \\
\hline Poultry meat wet & 254319 & 131188 & 0 \\
\hline Winery wet & 180054 & 68568 & 0 \\
\hline Red meat wet & 80129 & 71970 & 0 \\
\hline Distillery wet & 61367 & 51835 & 0 \\
\hline Fresh/frozen wet & 24284 & 26378 & 0 \\
\hline Cannery wet & 9897 & 18276 & 0 \\
\hline Dehydrators wet & 5463 & 14459 & 0 \\
\hline Orchard reside & 0 & 0 & 4196085 \\
\hline MSW green waste & 0 & 0 & 2931159 \\
\hline MSW lumber & 0 & 0 & 2569417 \\
\hline Field residue & 0 & 0 & 2343585 \\
\hline Almond shell & 0 & 0 & 565284 \\
\hline Almond hull & 0 & 0 & 490493 \\
\hline MSW paper & 0 & 0 & 274353 \\
\hline Walnut shell & 0 & 0 & 249919 \\
\hline Dehydrator dry & 0 & 0 & 133721 \\
\hline MSW cardboard & 0 & 0 & 122710 \\
\hline Rice hull & 0 & 0 & 118887 \\
\hline Cannery dry & 0 & 0 & 39162 \\
\hline Bakery dry & 0 & 0 & 21136 \\
\hline Olive fruit pit & 0 & 0 & 16188 \\
\hline Row crop residue & 0 & 0 & 4615 \\
\hline Grain chaff & 0 & 0 & 1718 \\
\hline Cotton gin trash & 0 & 0 & 710 \\
\hline MSW other organic & 0 & 0 & 357 \\
\hline Layer bedding & 0 & 0 & 90 \\
\hline Pullet bedding & 0 & 0 & 28 \\
\hline Broiler bedding & 0 & 0 & 5 \\
\hline Total & $5,004,986$ & $2,744,801$ & 14079621 \\
\hline
\end{tabular}

\section{Alternative Byproduct Markets:}

142 The role that compost, mulch, fertilizer, and other soil additives play in the economy goes beyond the 143 traditional farm and landscaping markets (CalRecycle, Caltran, CalFire).22-24 Mulches, which tend to be 144 comprised of chipped wood, and blends of wood chips, bark, straw, and compost are used in urban 145 settings by government bodies, like city Parks and Recreation departments and the state Dep. Of 146 Transportation CalTrans, to improve soil moisture retention around trees, protecting them from heat and 147 drought, to control weeds, to reduce runoff and fill in median strips along roads, and for beautification 
projects. Another large urban market for compost and mulches is construction. In California, the state water resources control board (SWRCB) enforces part of phase II of the Environmental Protection Agency National Pollutant Discharge Elimination System (NPDES) which requires stormwater management plans for small construction projects that disturb one or more acres of land. Organic matter can be applied on slopes and at specific points in and around the construction site to reduce erosion, improve stormwater infiltration and contaminant removal from stormwater, and restore lost SOM and nutrients. Straw, wood mulch, compost, and processed yard waste are common materials used during and after construction. California has another important market for compost, being the restoration and management of fire-damaged land (Table S6). Applying compost and mulches to fire damaged lands reduces soil exposure to wind and rain, replenishes SOM, provides gradual nutrient release that matches natural soil systems over time to promote regrowth (compared to synthetic fertilizer), and can provide stability to sloped land. In addition to damaged wildland, that may need restoration to protect watersheds and restore ecosystems services, compost can help restore damaged land in urban areas. Over 1,300 towns in wildland-urban interface areas have been identified as being at risk of wildfires in California. ${ }^{24}$

Table S6. Acres affected by wildfires, prescribed fires (Rx), and wild fire use (WFU). *Data for 2018 is approximated by the authors from CalFire. ${ }^{25}$

\begin{tabular}{llll}
\hline Year & Wildfire & Rx & WFU \\
\hline $2018^{*}$ & 1671203 & - & - \\
2017 & 1266224 & 49522 & 0 \\
2016 & 560815 & 46953 & 0 \\
2015 & 893362 & 46829 & 0 \\
2014 & 555044 & 36997 & 0 \\
2013 & 577675 & 48544 & 0 \\
2012 & 869599 & 56830 & 0 \\
2011 & 126854 & 59273 & 0 \\
2010 & 109529 & 72565 & 0 \\
2009 & 405585 & 93940 & 0 \\
2008 & 1375781 & 87416 & 29503 \\
2007 & 1087110 & 67678 & 1784 \\
2006 & 678919 & 71403 & 23717 \\
2005 & 202754 & 95095 & 12569 \\
2004 & 242057 & 79158 & 8369 \\
2003 & 793402 & 67782 & 41069 \\
2002 & 506696 & 88362 & 4138 \\
\hline
\end{tabular}

We convert acreage for specific markets to compost demand by gathering mass and volumetric loading rates, or by approximating these loading rates from nitrogen loading rates. Guidelines on compost and mulch application are specific to each market, but generally recommended application rates either do not exceed the average natural nitrogen in soil types or are targeted towards a specific crop and its assimilation capacity (Tables S7-S8). ${ }^{26}$ The slope of the land where the material is applied with also affect the depth of material application and the method for incorporation. For example, nitrogen assimilation capacity of prairie and rangeland used by Kellogg et al. can be used to convert these land types to $\mathrm{N}$ equivalents. ${ }^{27}$ 
Harvested acreage from the 2014 NASS USDA database for field crops, orchard and vineyards, and vegetable/row crops are converted to $\mathrm{N}$ equivalents of fertilizer application. Fertilizer load (lb N/acre crop type) is collected from Rosenstock et al. review of nitrogen application and consumption in California. These loads are the arithmetic average of recommended applications by agronomists and of farmer estimates, which varied significantly. Nitrogen application is reported for some crops in the NASS USDA database, but a number of factors affect the decision to apply fertilizer, which may vary from year to year. As such the Rosenstock values are assumed in this analysis.

A number of markets exist for soil amendments, like compost and mulch, that are not necessarily nutrientrich, but that provide valuable physiochemical services. We estimate that approximately 130 million cubic meters of compost per year could be either spread on land newly damaged by fires in a normal fire season, used on construction sites, or used to meet urban demand for parks and urban land maintenance. ${ }^{28}$ If mulch is required to improve the characteristics of digestate for these markets, anywhere from 46 to 260 million cubic meters of mulch may be required annually, based on the compost:mulch blending ratios found in literature.$^{26}$ In total, these markets could require approximately 8 MMT composted digestate and 16 to 92 MMT mulch. Assuming a moisture content of $50 \%$ for composted digestate and $15 \%$ for mulch, we estimate gross production potential of $10 \mathrm{Mt}$ composted digestate and $44 \mathrm{MMT}$ mulch from woody residues in 2014.

This suggests that large non-crop alternative markets are on the same order of magnitude as the potential quantities of composted digestate and mulch from Gross biomass residues (see SI for calculations). Having alternative markets on the same order of magnitude is important for diverting digestate from landfills in the case that rangeland is limited, but may also lead to competition for biomass residues or the byproduct. There are 382 active mulching and composting facilities throughout the state (CalRecycle SWIS), and these facilities may compete with the bioenergy sector for biomass residues, particularly those that contribute a majority of the state's potential source of biochar, such as tree residues.

Nutrient-rich amendments and fertilizers have particular value in the agricultural sector. We estimate that roughly 0.3 MMT of N could have been applied to harvested cropland based on the type of crops grown and harvested in 2014. Depending on assumed N composition of digestate, between 3 and 7 million BDT digestate could be direct to the cropland market, or anywhere from 22 to $51 \%$ of Gross potential digestate production. 
Table S7. Average nitrogen levels by ecoregion and average application rates by market. DOT:

203 Department of Transportation.

\begin{tabular}{|c|c|c|c|c|}
\hline Ecoregion or market & $\begin{array}{l}\text { Typical } \\
\text { nitrogen } \\
\text { levels } \\
\text { [lb/acre] }\end{array}$ & $\begin{array}{l}\text { Average } \\
\text { compost } \\
\text { application } \\
\text { [tons/acre] }\end{array}$ & $\begin{array}{l}\text { Average } \\
\text { volumetric } \\
\text { application [cubic } \\
\text { yards/acre] }\end{array}$ & Reference \\
\hline $\begin{array}{l}\text { Min total } N \text { to support } \\
\text { vegetation }\end{array}$ & 625 & 31.25 & & $\begin{array}{l}\text { Bradshaw et al } \\
1982^{29}\end{array}$ \\
\hline Drastically disturbed sites & 700 & 35 & & DOT $^{22}$ \\
\hline Desert grassland & 800 & 40 & & $\mathrm{DOT}^{22}$ \\
\hline $\begin{array}{l}\text { Min total } \mathrm{N} \text { to support } \\
\text { vegetation in decomposed } \\
\text { granite soils }\end{array}$ & 1100 & 55 & & $\begin{array}{l}\text { Vic Claassen } \\
\text { et al. }{ }^{26}\end{array}$ \\
\hline Shrub -steppe prairies & 4500 & 225 & & $\mathrm{DOT}^{22}$ \\
\hline Deep forest soils & 20000 & 1000 & & $\mathrm{DOT}^{22}$ \\
\hline Sparse vegetative cover & 50 & 2.5 & & $\mathrm{DOT}^{22}$ \\
\hline $\begin{array}{l}\text { Roadside mulch (not arid region } \\
<10 \text { " annual rainfall) }\end{array}$ & & & 270 to 400 & $\mathrm{DOT}^{22}$ \\
\hline $\begin{array}{l}\text { Parks and Recreation } \\
\text { (approximated from } \\
\text { demonstration in Los Angeles) }\end{array}$ & & & $\begin{array}{l}5,000 \text { to } 15,000 \text { for } \\
\text { city with } 16,000 \\
\text { acres }(4.95 \mathrm{lb} \\
\text { N/acre) }\end{array}$ & CalRecycle ${ }^{23}$ \\
\hline Fire damaged land & 2152 & & 270 & CalRecycle $^{23}$ \\
\hline
\end{tabular}

205 Table S8. Average application rate of nitrogen [lb/acre] by crop type for 2005.

\begin{tabular}{llll}
\hline Crop type & & Crop type & \\
\hline Pistachio & 7 & Cotton & 174 \\
Grapes, wine & 27 & Tomatoes, fresh market & 177 \\
Grapes, table & 43 & Wheat & 177 \\
Grapes, raisin & 44 & Almond & 179 \\
Beans, dry & 91 & Tomatoes, processing & 182 \\
Oranges & 95 & Broccoli & 190 \\
Peaches, cling & 102 & Lettuce & 193 \\
Nectarines & 104 & Strawberry & 193 \\
Plums, fresh & 104 & Onions & 212 \\
Avocado & 112 & Corn, sweet & 213 \\
Peaches, free & 113 & Carrots & 216 \\
Lemons & 123 & Cauliflower & 238 \\
Plums, dried & 130 & Potato & 248 \\
Rice & 130 & Celery & 259 \\
Walnut & 138 & Peppers, chili & 300 \\
Melons, watermelon & 151 & Peppers, bell & 346 \\
Melons, cantaloupe & 163 & & \\
\hline
\end{tabular}




\section{Section 2. Additional Results}

207 We estimate 4.6 million bone dry tonnes (BDT) of digestate per year could be produced from the gross biomass residues generated by agriculture, industry, and cities by 2050, in addition to 0.5 million BDT biosolids we estimate could be diverted from landfills (Figure 3). Digestion of all manure contributes an additional 8.7 million BDT/yr of digestate requiring disposal, highlighting the magnitude of the dairy

211 industry in California. Nearly half of gross biochar production potential (3.8 million BDT/yr) is derived

212 from the forestry industry, with the remaining half coming from low-moisture agriculture and municipal

213 wastes.

214 Wet MSW accounts for $66 \%$ of non-manure digestate production, followed by wet food processing 215 wastes at $16 \%$. Gross non-manure digestate production increased by $28 \%$ between 2014 and 2050, with contributions from different sectors remaining relatively stable, and gross potential from manure increasing 13\%. The composting process decreases the mass of digestate requiring land disposal by $57 \%$ (Figure S3). Compared to our Gross scenario, our Technical scenario generates 61\% lower digestate from non-manure sources (Figure 3).

Our projections suggest that gross biochar potential would increase by $7 \%$ by 2020 and increase by $22 \%$ to 9.4 million BDT of biochar by 2050 from changes in gross resource production alone (Figure S4). Technology adoption that achieves high biochar yields could put Gross biochar slightly over 13.6 million BDT biochar per year by 2050, however technologies that generate the highest quality biogas may only produce 7.5 million tonnes biochar per year. Biochar production in the Tech scenario is $48 \%$ lower than 225 the Gross scenario.

As the bioenergy build out model we apply in our Market and Policy scenarios focuses on urban and crop residues, and does not presently allocate forestry residues or manure to facilities, we have only our Gross and Tech scenario estimates to describe biochar and digestate production from these large biomass

229 residue sources.

If disposal were to stop in 2150 the savings would decline as the byproducts decay and the soil response declines. ${ }^{30-32}$ Furthermore, it is possible that GHG emissions from the stored $\mathrm{C}$ could be rapidly emitted in the event of wildfires, and this risk should be carefully considered when picking land for carbon sequestration. ${ }^{33}$ In our Market and Technical scenarios, we find that 100 years of annual byproduct disposal could provide a cumulative GHG offset ranging from 50 to $400 \mathrm{MMTCO}_{2}$ eq, with an additional 80 to 300 MMTC (equivalent to $290-1100 \mathrm{GtCO}_{2}$ eq) remaining on soils. 


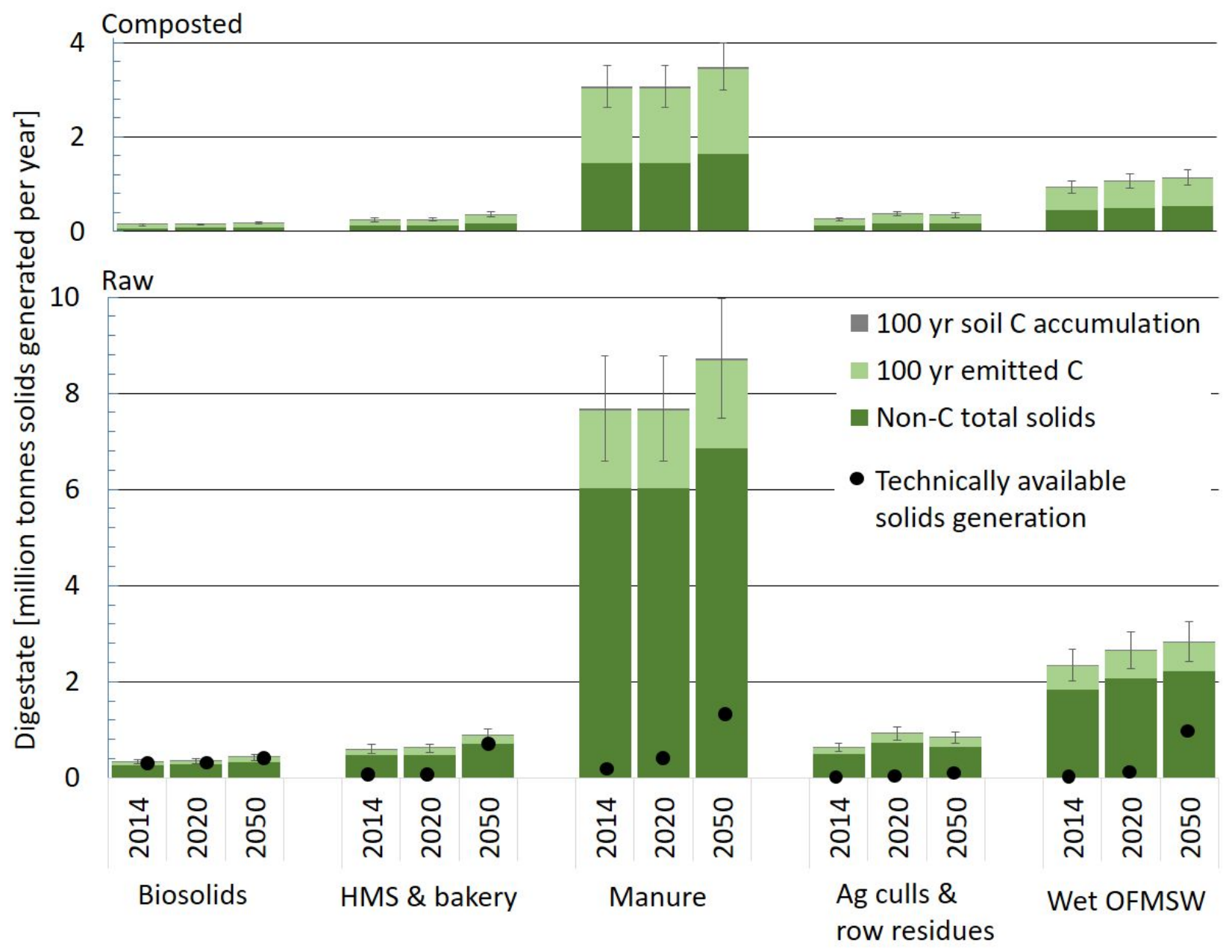

237 Figure S3. Anaerobic digestion byproduct production, carbon content, and soil carbon contribution 238 remaining after 100 years of decay on grasslands for the base scenario. Results for years 2014, 2020, and 2392050 presented for gross raw digestate (bottom panel), gross composted digestate (top panel). Technically 240 available raw digestate (dot) is estimated in 2050 for the Tech Scenario, and is approximated from the 241 operation start date of existing stand-alone $\mathrm{AD}(\sim 11)$ and manure dairy digesters $(\sim 30)$ in California. ${ }^{18,34}$ 


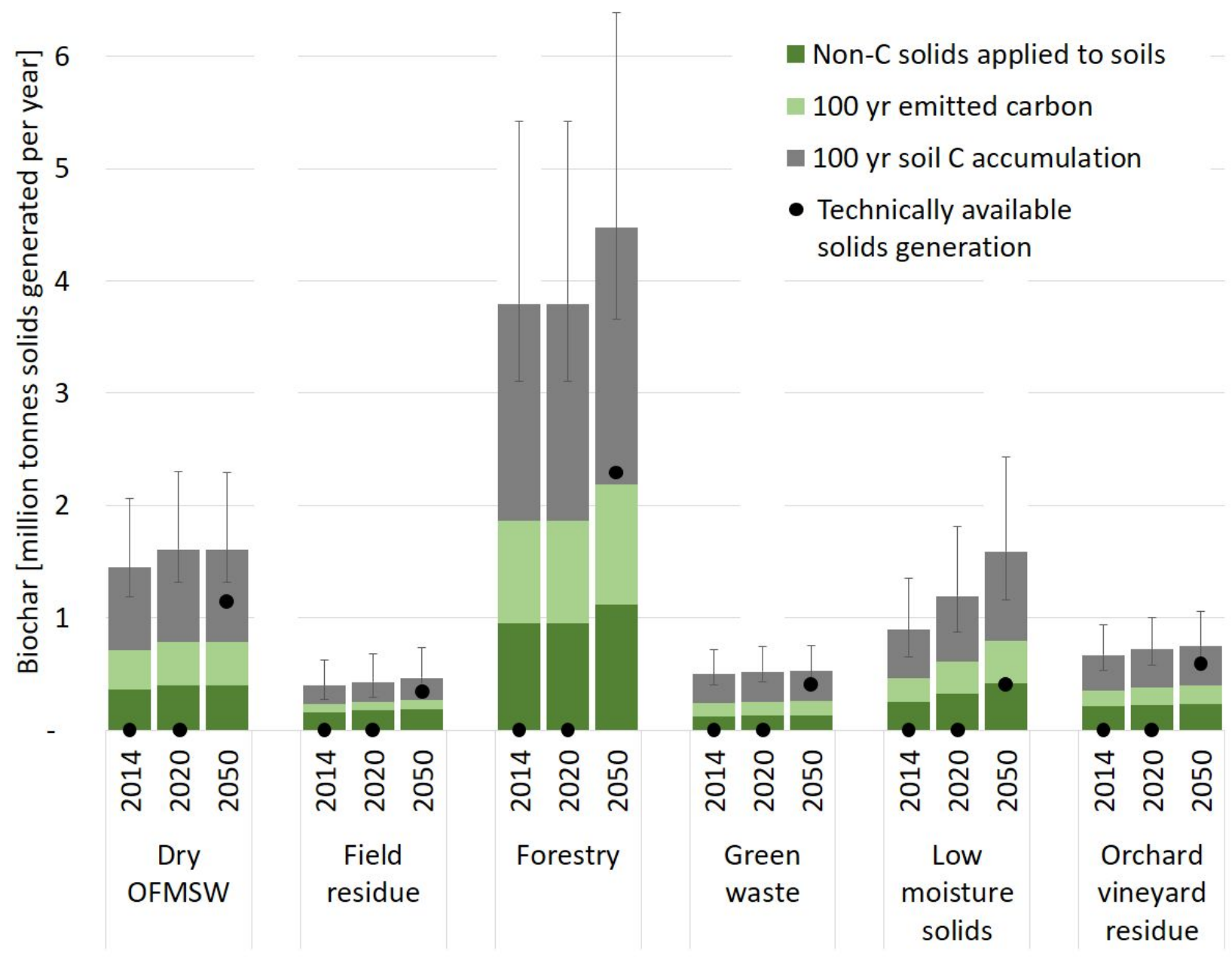

243 Figure S4. Gasification byproduct production, carbon content, and soil carbon contribution remaining 244 after 100 years of decay on grasslands for the base scenario. Results for years 2014, 2020, and 2050 are 245 presented for gross biochar. Technically available biochar (dot) is estimated in 2050 for the Tech 246 Scenario, and is assumed to be zero for 2014 and 2020 as there are no large scale gasification facilities 247 operating in California as of 2019. 
Composted digestate
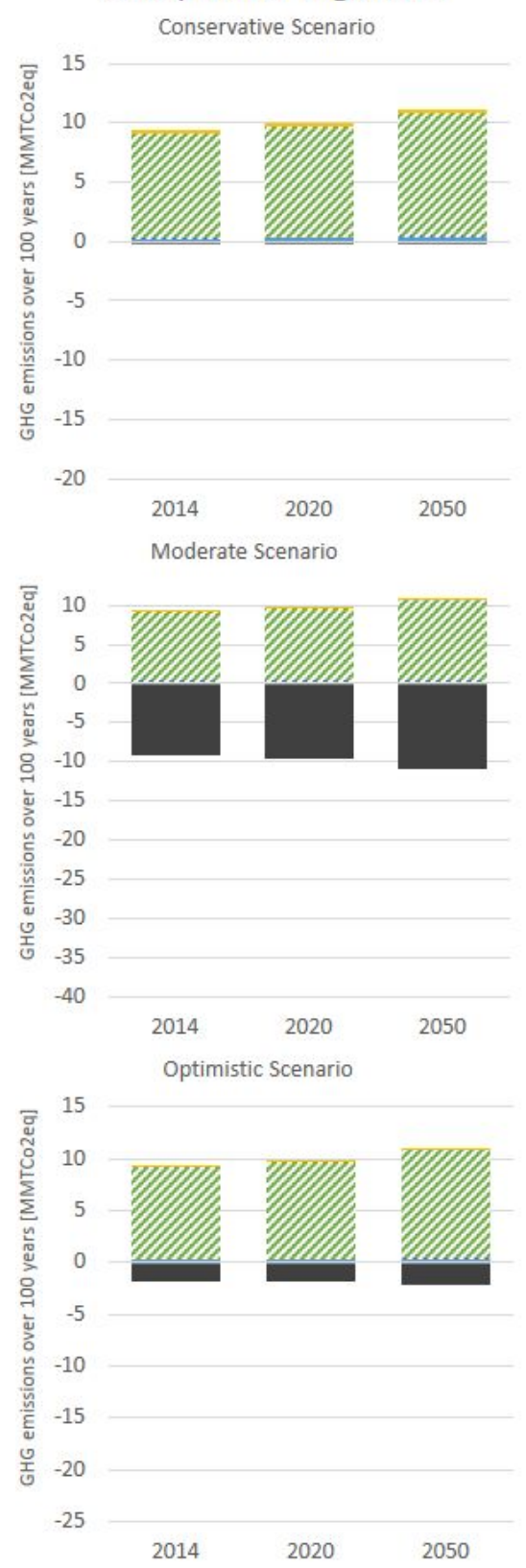

= Composting $\mathrm{CH} 4 \quad$ \#Composting $\mathrm{CO} 2$

- Byproduct decay $\mathrm{N} 2 \mathrm{O}$ \# Byproduct decay CO2

- NPP effect
Raw digestate

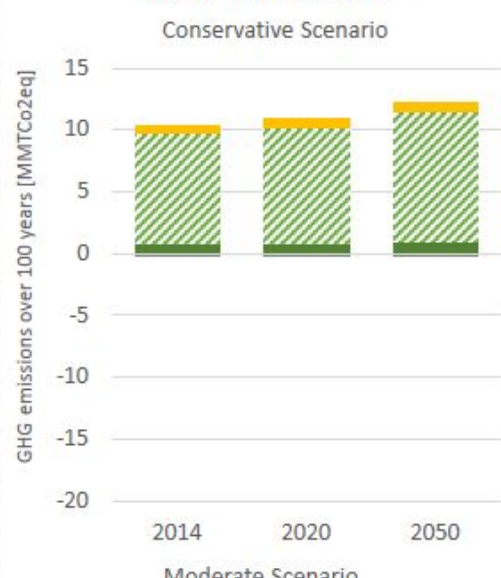

Moderate Scenario

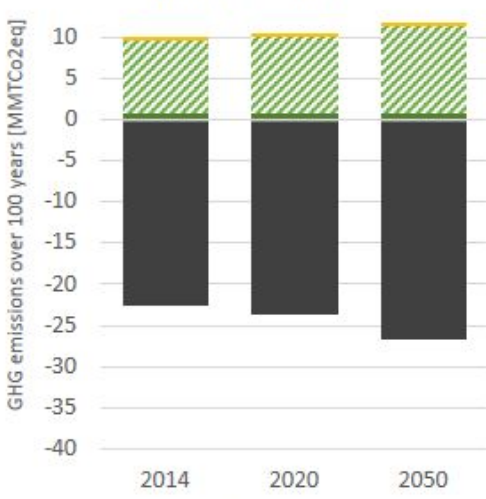

Optimistic Scenario

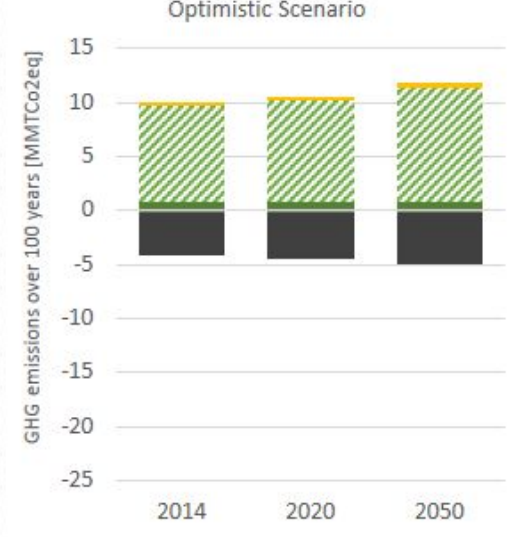

Eyproduct decay $\mathrm{CH} 4$

Trucking and tilling
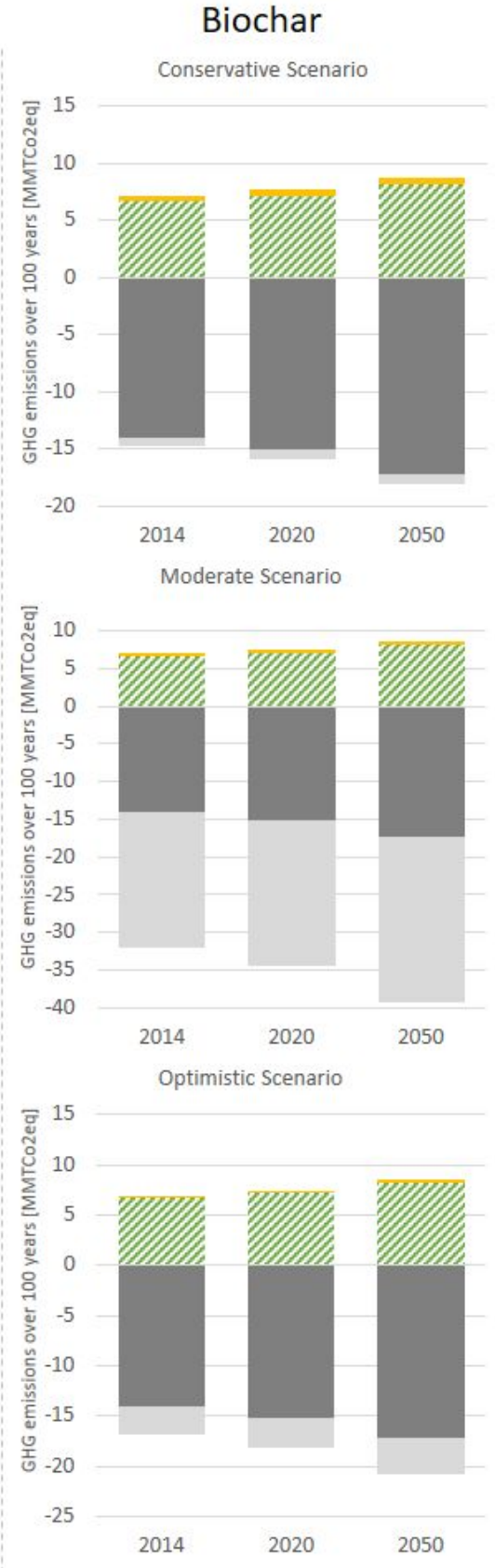

Figure S5. Attributional life-cycle GHG emissions for a single application of biochar and digestate, either raw or composted, on working land in California, aggregated over 100 years. Results are presented for the 251 organic residues generated in 2014, 2020, and 2050 inventories for conservative, moderate, and optimistic 252 Gross scenarios. Direct $\mathrm{CO}_{2}$ from byproduct decay or composting is shown for reference, but not included 253 in the net GHG emissions. 


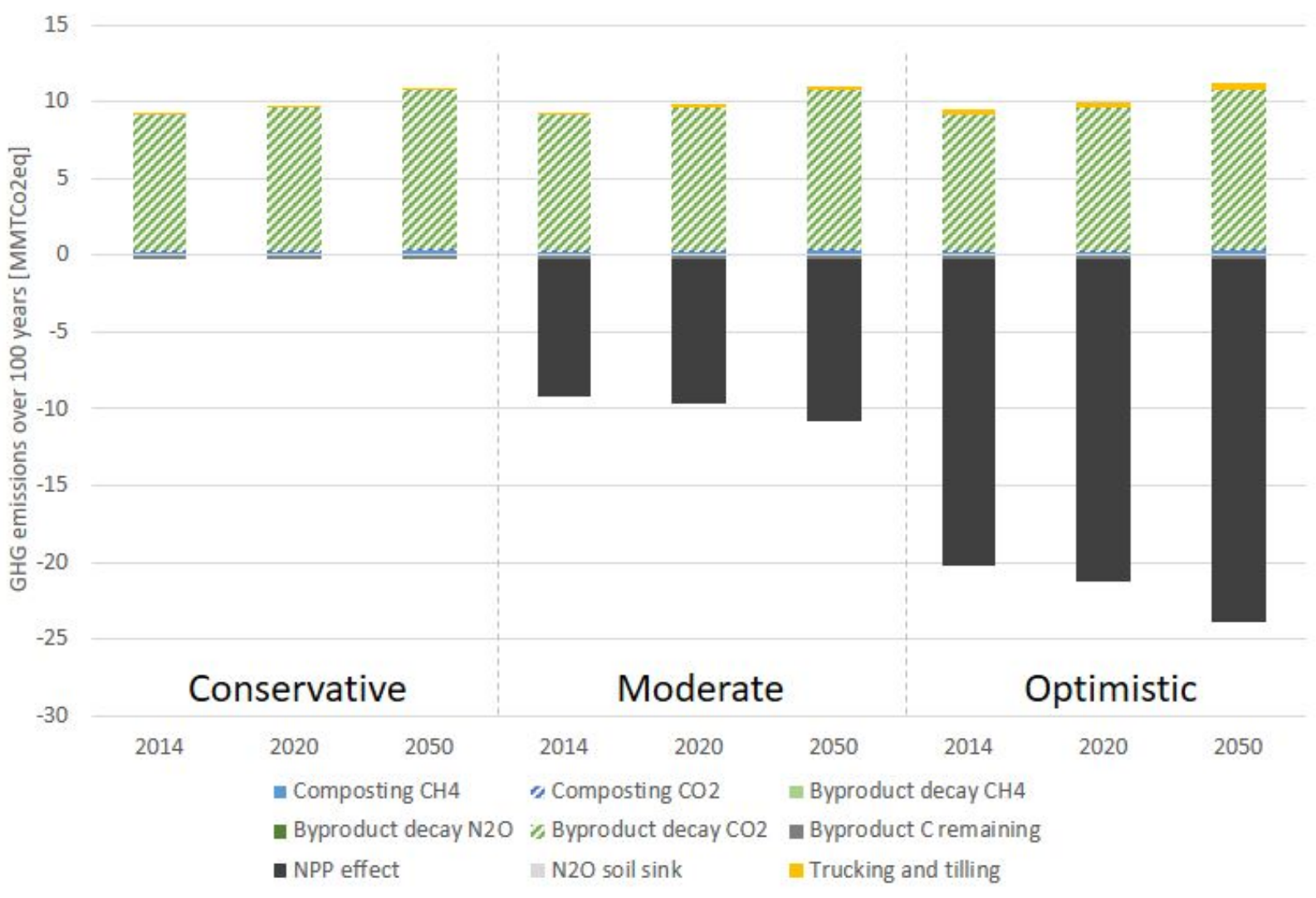

255 Figure S6. Impact of holding composted digestate application loading rate [tonnes/acre] constant across 256 Gross scenarios on life-cycle greenhouse gas emissions profile. 


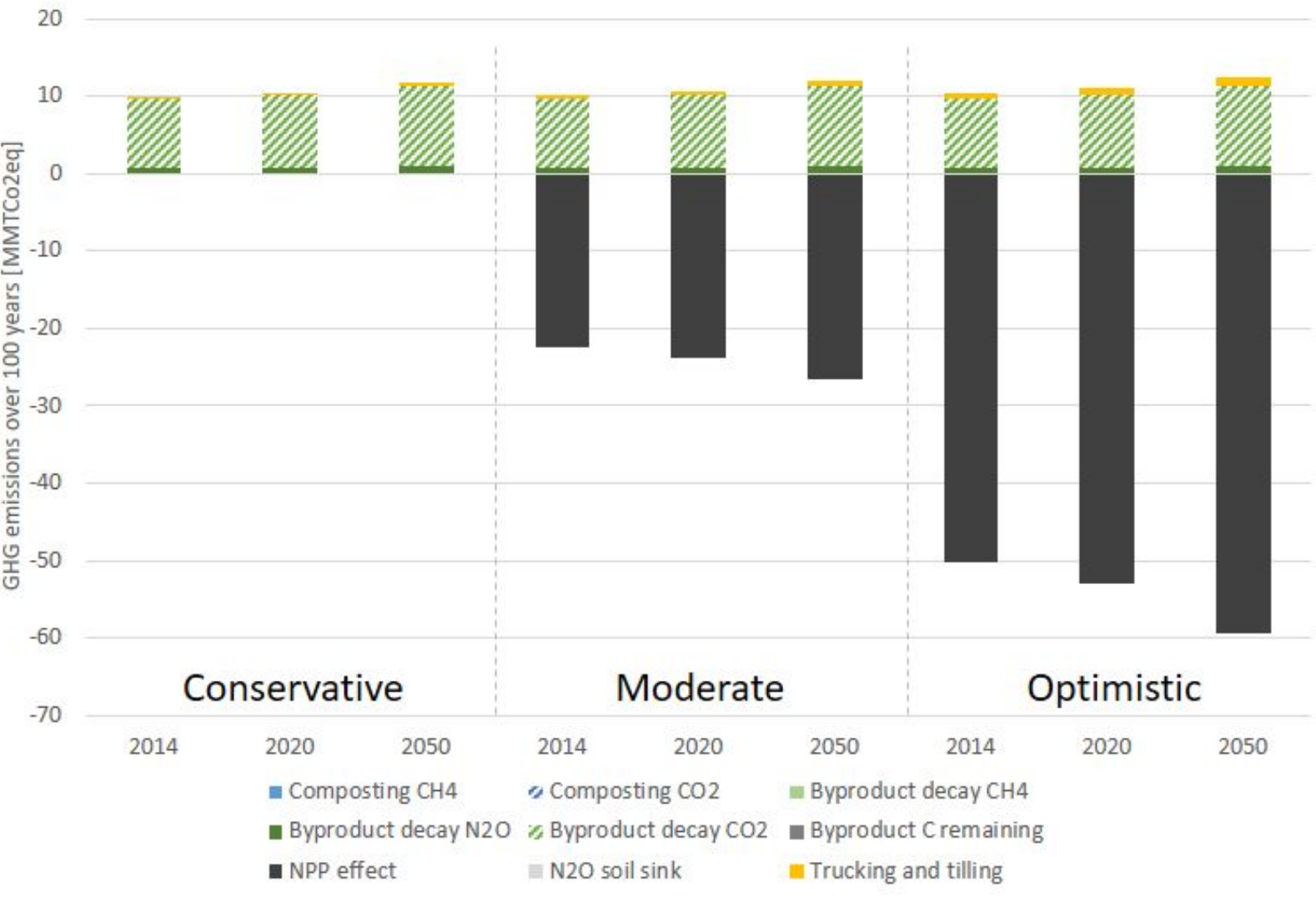

258 Figure S7. Impact of holding raw digestate application loading rate [tonnes/acre] constant across Gross 259 scenarios on life-cycle greenhouse gas emissions profile. 


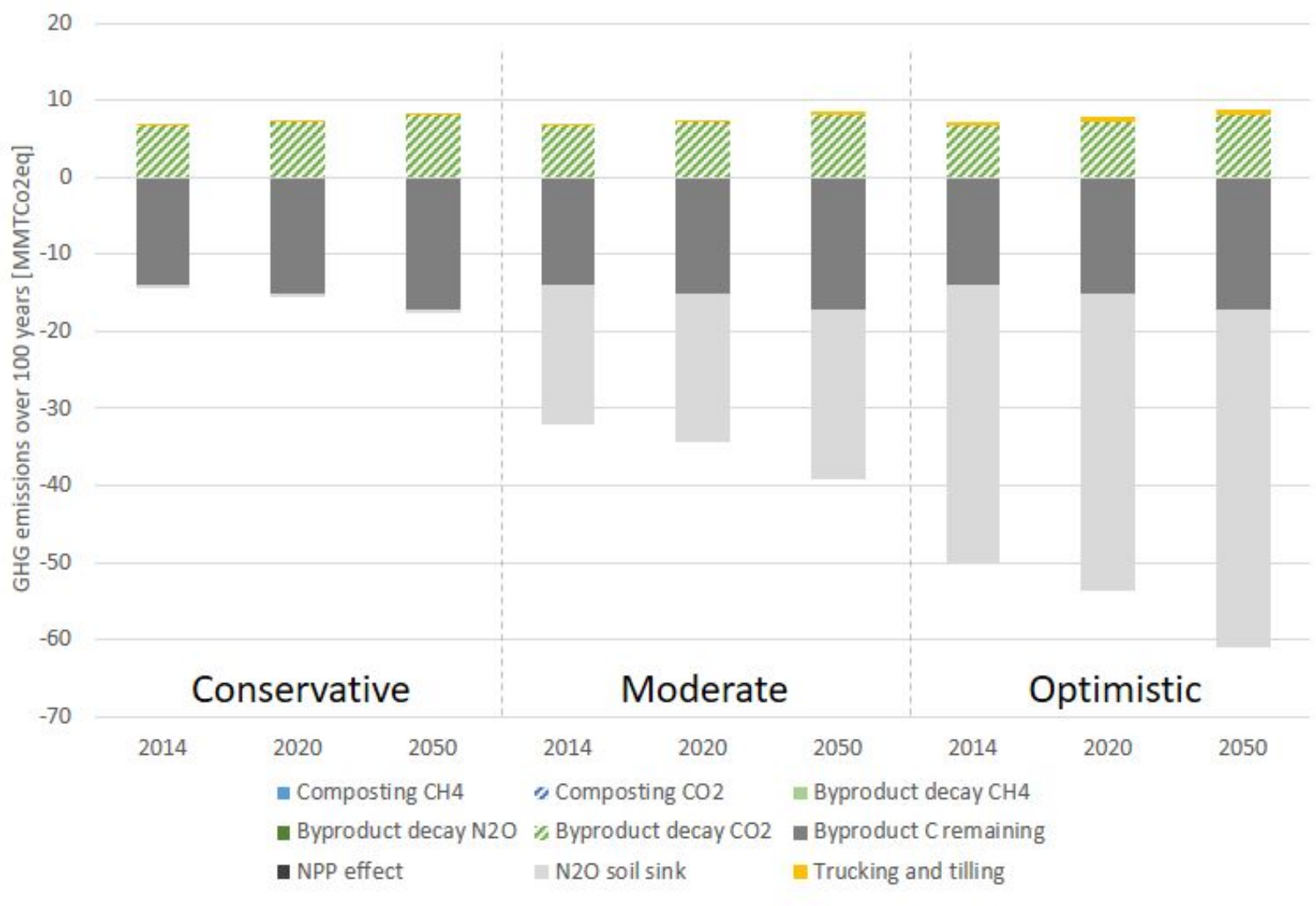

261 Figure S8. Impact of holding biochar application loading rate [tonnes/acre] constant across Gross 262 scenarios on life-cycle greenhouse gas emissions profile. 


\section{Alternative byproduct markets:}

264 Crops grown and harvested in California require $\sim 290,000$ tonnes of N, according to 2014 production.

265 This gross nitrogen demand is likely met with synthetic fertilizers, biosolids, and manure rich in nitrogen,

266 however the actual materials supplied are difficult to estimate as records are limited.

267 Approximately 160 million cubic yards of compost per year could be spread on land newly damaged by

268 fires in California. ${ }^{21}$ With an estimate 40,000 acres of new construction development a year in California

269 to meet growing populations, construction could consume 3.5 million cubic yards of compost per year. If

270 California has approximately 7.1 million acres of developed land, then approximately 4.5 million cubic

271 yards of compost per year could be used for parks, recreational activities, schools, and other urban

272 markets. A mulch demand anywhere from 60-340 million cubic yards is possible depending on the

273 compost-mulch blending ratio used in land management projects. ${ }^{19}$ When we convert these applications to

274 nitrogen and add them to the nitrogen demand on croplands, we estimate a nitrogen market in California

275 of 19 million tonnes of $\mathrm{N}$. This nitrogen market could be met with synthetic fertilizers or with materials

276 rich in nitrogen such as manure, digestate and biosolids.

277 However, land managers may prefer materials with proven properties such as synthetic fertilizers and 278 manure. Claassen and Young explored the concern expressed by California land managers that applying 279 compost on degraded field sites leads to nutrient and metal leaching and runoff into waterbodies. They

280 found that even during heavy rains there is a minimal risk of nutrient runoff when using composts created from yard wastes, especially when well incorporated into soils and applied with mulch. ${ }^{26}$ Similar evidence will be needed for bioenergy byproducts to ensure low metal and nutrient runoff from material blends that use nutrient rich digestate and nutrient and metal rich ash. On the other hand, many markets discussed in this analysis value nutrient content along with improvements and protection of soil quality, and it would seem that digestate could have a strong advantage over conventional compost blends.

\section{Perspective: hydrological benefits}

Improving water storage capacity in soils leads to drought resistance and improved productivity, and can lower irrigation needs and fire risk. This is particularly true in the Northern Central Valley and in the higher elevation foothills where ample precipitation makes improvements to soil water holding capacity beneficial. Future research could focus on co-optimizing biochar and digestate application on the basis of both GHG and water use impacts. Flint and colleagues estimated the hydrological impacts of a 3- 8\% increase in SOM on California working lands, including critical rangelands, on the basis of increased groundwater recharge, estimated increases in NPP, and estimated decreases in cropland irrigation. ${ }^{35}$ Their analysis suggests a 3 to $6 \%$ reduction in climate water deficit (proxy for cropland irrigation), a 1 to $3 \%$ increase in AET (proxy for NPP), and a 12 to $16 \%$ increase in groundwater recharge on grasslands. This higher recharge is equivalent to 0.9 million acre-feet per year ( 300 billion gallons per year). 


\section{References}

299 1. Board, C. A. R. 2018 Edition; California Greenhouse Gas Emissions for 2000 to 2016; 2018.

$300 \quad 2 . \quad H u n t s i n g e r$, L.; Oviedo, J., Ecosystem services are social-ecological services in a traditional

301 pastoral system: The case of California's Mediterranean rangelands. Ecology and Society 2014, 19 (1), 8.

$3023 . \quad$ Macaulay, L.; Butsic, V., Ownership characteristics and crop selection in California cropland.

303 California Agriculture 2017, 71 (4), 221-230.

304 4. Silver, W. L.; Vergara, S. E.; Mayer, A. Carbon sequestration and greenhouse gas mitigation 305 potential of composting and soil amendments on California's rangelands; California Natural Resources 306 Agency: 2018; p 62.

307 5. California Rangeland Conservation Coalition, T. N. C., Priority Rangeland Conservation Areas. 308 https://databasin.org/datasets/4e24786c97f04bdf8f91d0fc16013a88, 2007.

309 6. Ronsse, F.; Van Hecke, S.; Dickinson, D.; Prins, W., Production and characterization of slow pyrolysis biochar: influence of feedstock type and pyrolysis conditions. Gcb Bioenergy 2013, 5 (2), 104115.

312 7. Claoston, N.; Samsuri, A.; Ahmad Husni, M.; Mohd Amran, M., Effects of pyrolysis temperature 313 on the physicochemical properties of empty fruit bunch and rice husk biochars. Waste Management \& 314 Research 2014, 32 (4), 331-339.

$315 \quad 8 . \quad$ Lam, S. S.; Liew, R. K.; Cheng, C. K.; Rasit, N.; Ooi, C. K.; Ma, N. L.; Ng, J.-H.; Lam, W. H.; Chong, C. T.; Chase, H. A., Pyrolysis production of fruit peel biochar for potential use in treatment of palm oil mill effluent. Journal of environmental management 2018, 213, 400-408.

318 9. Angın, D., Effect of pyrolysis temperature and heating rate on biochar obtained from pyrolysis of safflower seed press cake. Bioresource technology 2013, 128, 593-597.

10. Demirbas, A., Effects of temperature and particle size on bio-char yield from pyrolysis of agricultural residues. Journal of analytical and applied pyrolysis 2004, 72 (2), 243-248.

11. Demirbas, A., Effect of temperature on pyrolysis products from four nut shells. Journal of analytical and applied pyrolysis 2006, 76 (1-2), 285-289.

12. Zabaniotou, A.; Roussos, A.; Koroneos, C., A laboratory study of cotton gin waste pyrolysis. Journal of Analytical and Applied Pyrolysis 2000, 56 (1), 47-59.

13. Astals, S.; Nolla-Ardèvol, V.; Mata-Alvarez, J., Anaerobic co-digestion of pig manure and crude glycerol at mesophilic conditions: Biogas and digestate. Bioresource Technology 2012, 110, 63-70. 14. Pognani, M.; D'Imporzano, G.; Scaglia, B.; Adani, F., Substituting energy crops with organic fraction of municipal solid waste for biogas production at farm level: A full-scale plant study. Process Biochemistry 2009, 44 (8), 817-821.

15. Tambone, F.; Scaglia, B.; D'Imporzano, G.; Schievano, A.; Orzi, V.; Salati, S.; Adani, F., Assessing amendment and fertilizing properties of digestates from anaerobic digestion through a comparative study with digested sludge and compost. Chemosphere 2010, 81 (5), 577-583.

16. Moset, V.; Poulsen, M.; Wahid, R.; Højberg, O.; Møller, H. B., Mesophilic versus thermophilic anaerobic digestion of cattle manure: methane productivity and microbial ecology. Microbial biotechnology 2015, 8 (5), 787-800.

17. Williams, R. B.; Jenkins, B. M.; Kaffka, S. An assessment of biomass resources in California, 2013 DRAFT; California Energy Commission: 2015; $\mathrm{p} 70$.

18. Breunig, H. M.; Jin, L.; Robinson, A.; Scown, C. D., Bioenergy potential from food waste in California. Environmental science \& technology 2017, 51 (3), 1120-1128.

19. Breunig, H. M.; Huntington, T.; Jin, L.; Robinson, A.; Scown, C. D., Temporal and geographic drivers of biomass residues in California. Resources, Conservation and Recycling 2018, 139, 287-297. 20. Scown, C.; Robinson, A.; Breunig, H.; Jin, L.; Huntington, T.; Smith, S.; Devkota, J.; Nordahl, S.; Baral, N. Paths to Sustainable Distributed Generation through 2050: Matching Local Waste Biomass 
Resources with Grid, Industrial, and Community Needs; Lawrence Berkeley National Laboratory: Sacramento, CA, 2019; p 242.

21. Woolf, D.; Amonette, J. E.; Street-Perrott, F. A.; Lehmann, J.; Joseph, S., Sustainable biochar to mitigate global climate change. Nature communications 2010, 1, 1.

22. Transportation, C. D. o., Incorporate Materials. 2016.

23. CalRecycle, Organic Materials Management: Using Compost and Mulch. 2016.

24. Protection, C. D. o. F. a. F. Characterizing the fire threat to wildland-urban interface areas in California; Sacramento.

25. Center, N. I. F., Historical year-end fire statistics by state (source NICC). 2019.

26. Claassen, V.; Young, T. Model Guided Specification for Using Compost and Mulch to Promote Establishment of Vegetation and Improvement in Stormwater Quality; California Department of Transportation: Sacramento, 2010; $\mathrm{p} 162$.

27. Kellogg, R.; Lander, C.; Moffitt, D.; Gollehon, N. Manure nutrients relative to the capacity of cropland and pastureland to assimilate nutrients: spatial and temproal trends for the United States; USDA: 2000; $p 140$.

28. Center, N. I. F., Historical year-end fire statistics by state (source NICC). 2016.

29. Bradshaw, A. D.; Marrs, R.; Roberts, R.; Skeffington, R., The creation of nitrogen cycles in derelict land. Phil. Trans. R. Soc. Lond. B 1982, 296 (1082), 557-561.

30. Sathre, R.; Masanet, E., Long-term energy and climate implications of carbon capture and storage deployment strategies in the US coal-fired electricity fleet. Environmental science \& technology 2012, 46 (17), 9768-9776.

31. Anderson, K.; Peters, G., The trouble with negative emissions. Science 2016, 354 (6309), 182183.

32. Fuss, S.; Canadell, J. G.; Peters, G. P.; Tavoni, M.; Andrew, R. M.; Ciais, P.; Jackson, R. B.; Jones, C. D.; Kraxner, F.; Nakicenovic, N., Betting on negative emissions. Nature climate change 2014, 4 (10), 850. 33. Czimezik, C.; Preston, C.; Schmidt, M.; Schulze, E., How surface fire in Siberian Scots pine forests affect soil organic carbon in the forest floor. Global Biogeochemial Cycles 2003, 17 (1), 20-1: 20-14.

34. Cares, D. Digesters: Reducing Emissions and Creating Clean Energy. https://www.dairycares.com/dairy-digesters (accessed May 16 2019).

35. Flint, L. E.; Flint, A. L.; Stern, M. A.; Myer, A.; Silver, W.; Casey, C. F.; Franco, F.; Byrd, K.; Sleeter, B.; Alvarez, P.; Creque, J.; Estrada, T.; Cameron, D. Increasing soil organic carbon to mitigate greenhouse gases and increase climate resiliency for California; California natural resources agency: 2018; p 113. 